IdeAs

Idées d'Amériques

$14 \mid 2019$

Populismes dans les Amériques

\title{
Questions of Epic and Lyric: The Challenge of Walt Whitman
}

Thomas C. Austenfeld

\section{OpenEdition}

1 Journals

\section{Electronic version}

URL: https://journals.openedition.org/ideas/6618

DOI: 10.4000/ideas.6618

ISSN: 1950-5701

\section{Publisher}

Institut des Amériques

\section{Electronic reference}

Thomas C. Austenfeld, "Questions of Epic and Lyric: The Challenge of Walt Whitman", IdeAs [Online], 14 | 2019, Online since 01 October 2019, connection on 21 September 2021. URL: http:// journals.openedition.org/ideas/6618; DOI: https://doi.org/10.4000/ideas.6618

This text was automatically generated on 21 September 2021

\section{(c) (i) (9)}

IdeAs - Idées d'Amériques est mis à disposition selon les termes de la licence Creative Commons Attribution - Pas d'Utilisation Commerciale - Pas de Modification 4.0 International. 


\title{
Questions of Epic and Lyric: The Challenge of Walt Whitman
}

\author{
Thomas C. Austenfeld
}

1 The genres of Whitman's most famous poems and the consequences to be drawn from their classification have been debated at least since the middle of the past century. Depending on the prevailing critical spirit of a given decade, critics have sought to enlist Whitman in their respective versions of literary history. F.O. Matthiessen suggested in American Renaissance that Whitman's poetry could be understood through the analogies of oratory, opera, and ocean (Matthiessen F.O., 1941 : 549-577). These three manifestations have epic features in common, namely extended size, large or universal "audience" or spectatorship, and sublime power. Roy Harvey Pearce argued that Whitman was the necessary bridge between Joel Barlow's post-revolutionary but undervalued Columbiad and Ezra Pound's desultory Cantos: all three authors seek to come to terms with the idea of America and develop more or less appropriate forms of epic representation. Instead of memorializing a hero, they poetically create one (Pearce R. H., 1959 : 363). In a different vein, Bill Hardwig diagnosed in Whitman primarily the disruptive use of elements of the epic tradition in order to show all the more clearly how America was not going to be like ancient empires (Hardwig B. $2000: 166,170)^{1}$. In every case, a generalized understanding of "epic" as large, dignified, built on classical models and connected with the nation served as the foil against which Whitman's work was evaluated and seen as either conforming, modifying, or rejecting.

2 Situated in temporal terms halfway between these critics, James E. Miller offered a compound argument: the subtitle of his study, Whitman's Legacy in the Personal Epic, claimed Whitman as originator of a characteristically American genre, while his title, The American Quest for a Supreme Fiction, generalized the argument of Wallace Stevens's long poem by investing it with a Romantic quest-motif. Miller concluded in a Whitmanesque manner:

This is an epic poet who will break all the rules for the epic, but insist on writing an epic anyway (...) The book (...) had more beginning, middle, and end than a merely miscellaneous collection of lyric poems. (Miller J. E., 1979 : 33) 
Miller then proposed the designation "Lyric-Epic" (Miller J. E., 1986) and further elaborated his argument in a 1992 book. According to Miller, "Lyric-Epic" can be understood as Whitmanesque because it resolves a contradiction by accepting it as intentional. Crediting ancient epics for their form and Edgar Allan Poe for his insistence on lyric brevity, Miller argues, Whitman tries to have it both ways by bringing into existence a "new American genre, the personal or lyric-epic" (Miller J. E., 1986 : 291). Miller also acknowledges Whitman's original articulation of sexual joy as a structural feature of his work.

However, I believe that the question of having to decide between lyric or epic as Whitman's form may present us with a false dichotomy which is not resolved even with a "both/and" response. Whitman's paradoxes and acceptance of contradiction are well known: "Do I contradict myself? / Very well, then, I contradict myself" says the speaker in section 51 of "Song of Myself." But the speaker continues: "(I am large, I contain multitudes.)" In other words: the large size of Whitman's imagination and of his poem equally point to his temperamental inclination towards the epic. Still, literary critics want more when they evoke the question of genre.

Genre, as Heather Dubrow asserted, "functions much like a code of behavior established between the author and his reader" (Dubrow H., $2014: 2$ ). As we read a text, it teaches us through its generic markers how it wants to be read. The form guides our understanding but also limits it. Readers know that a long poem in elevated style that focuses on a hero and implicates the fate of a people or nation is likely to be an epic and wants to be read as such. But when sufficient evidence to the contrary-lack of followthrough, choppy structure, low style and subject matter (what else could a poignantly democratic country produce?), an unconventional anti-hero-gets in the way, readers' expectations are thwarted and they decide that the work before them is not an epic after all. What remains? It must be a collection, however organic, of multiple lyrics. But this does not satisfy, either. The national sweep, the pathos-filled invocations, the insistent exclamation points signal at least a public oratory more compatible with epos than with the largely private lyric.

Thus, when reading about Whitman's epic impulse, we activate our assumptions about "epic," and these mostly direct us towards notions of size. In the Walt Whitman Archive, for example, David Baldwin particularly addresses the question, not of "epic" as such, but of "Epic Structure," as he concludes:

Whatever arguments may be made against the work's being an epic, Leaves of Grass is undeniably of such proportions. While the term epic might well be jettisoned in favor of another more flexible one, such as architectonic, with its distinguished tradition it remains suitable for honoring Whitman's truly magnificent accomplishment. (Baldwin D., concluding paragraph).

In Whitman, size clearly matters, but in literary criticism, it is not enough.

Generic attributions must generate new knowledge in order to be justified. In resuscitating the debate over Whitman's genre, I ask what new insights we can gain with the help of recent theories of the epic and the lyric. I query how our reading of Whitman might be enriched if we had more clarity about the question we ask when we raise the notion of genre. In what follows, I formulate the questions that may lead us to some tentative answers. 


\section{"Epic" as noun or adjective?}

9 First, we must carefully state what part of speech we invoke and what part of Whitman's work we examine when we look for "epic." If we use "epic" as noun, "Song of Myself" might qualify as an epic within Whitman's canon. Or are we referring to the entire Leaves of Grass through all of its eight editions as the epic accomplished over the course of a lifetime? Now that critics have recently paid more attention to Whitman's other works, Specimen Days (Tuggle L., 2017), or the reassembled Calamus (Karbiener K., 2019), or the newly-discovered "Manly Health and Training" or Life and Adventures of Jack Engle (Turpin Z., 2017), none of which is epic by any stretch, is it more convenient to classify just a portion of Whitman's work as his "epic" and not others? In other words: did he write an epic, namely "Song of Myself," but also a novel, lyrical poems, and journalism? If so, we can stop calling Whitman an "epic" poet and can instead concentrate on those texts that invoke traditional epic requirements, whether they fulfill or thwart them.

10 Alternately, we can use "epic" as an adjective to describe Whitman's epic impulse, his seeming inability to restrain himself, and his impetuous need to enlarge everything to cosmic scale, mowing down mercilessly any real or imagined (or cognitive or conceptual) obstacle in his path. Used in this way, "epic" as an adjective merely provides a way to avoid more clinical terms of opprobrium such as uncontrolled, prolix, repetitive, or formulaic. I propose to abandon "epic" as a generic adjective when speaking about Whitman's style. His style, when reaching for greatness, is infused with pathos and oratorical; it is prophetic and visionary, but to designate it as "epic" serves little purpose. His reach for elevated style and Latinate syntax was not uncommon among his contemporaries. Situated in its time, Whitman's voice is a unique but still characteristic, profoundly $19^{\text {th }}$-century voice that his contemporaries either understood or, even more interestingly, understood well enough to satirize. Epic poets do not get satirized in the normal order of things.

\section{National, literary, personal}

11 Second, it is worth distinguishing more carefully between national epics and literary epics when we apply the noun "epic" to part or all of Whitman's work. "Epic" suggests size first of all, as we have seen: before the emergence of novels, epics were simply the largest literary works around. Yet national epics of heroes and etiologies of a people's or nation's coming into existence are by no means coherent or textually unified; rather, they generally originate in the oral tradition, are at some point collected and codified, perhaps given a unitary authorial voice by a redactor, but still, they are recognizably grown rather than shaped. Gilgamesh, Beowulf, The Iliad, The Nibelungenlied are stories coming down to us from the deep dark past of oral history, having been turned into texts only at a much later stage. By contrast, literary epics such as The Aeneid, Gerusalemme Liberata, Paradise Lost are visibly shaped by their (known) authors and seek intentionally to cast a kind of global appeal and ambition. Even if The Aeneid is "just" the story of Rome's founding, Rome was the world, and so the text is global. The global ambitions of Tasso and Milton are evident from the stakes they attribute to the liberation of Jerusalem or, larger yet, to the origin of Man's Fall, where Milton takes on "things unattempted yet in prose or rhyme" (Paradise Lost, Book I, line 16). 
12 If we determine that Whitman sought to write a national epic, the story of America, a collection of parts of which he was merely the receiver, recorder, and conduit, then every lyrical sequence in his work can usefully be examined for itself before it takes its place in the larger scheme. If, on the other hand, he sought to write a literary epic, with a plan for its direction and completion, deliberately shaped by a towering authorial presence, then we should examine each lyrical portion primarily in its function as a part of the whole and only secondarily in and of itself. Minimally then, we always need to specify what kind of epic intention we refer to when we say "epic" in connection with Whitman.

Ezra Pound's quip, "an epic is a poem including history" can lead the way, but it does not suffice. It suggests that "history" is not normally a part of poetry. My reading of the entire Leaves of Grass suggests again and again that Whitman's historical comparisons with other epics serve as scenery, but are not action. Responding repeatedly to a perceived need to justify his work, Whitman gestures towards past realms and kingdoms across the globe and across recorded history only to further the contrast with his present (and future!) America. Ancienneté has no ethical validity in Whitman. His mythic hero, the poet who bestrides the land, characteristically disappears by the end of the long poem ostensibly centered around him, "Song of Myself." While Whitman's speaker repeatedly gives us "Americans" in their manifold variations, he refers to himself only as "an" American, not "the" American. Instead of defining himself as a model for others, this speaker suggests the many possibilities for being, or for coming into being. Each individual, American or not, is challenged to become himself or herself on their own, in the way that suits them best.

In contrast to national epics whose mythic heroes are meant to be emulated, at least aspirationally, "Walt" is no such hero. Readers must become their own heroes, "Walt" is unique. The familiar features of a national epic do appear intermittently, for example, in Section 34 of "Song of Myself" in the episode commemorating the 1836 Goliad Massacre in the Texas Revolution. The features of a literary epic appear in such passages as the dialogue (or perhaps sexual congress?) between self and soul in Section 5 of "Song of Myself." Yet clearly non-epical passages, such as the "Twenty-eight young men" episode in Section 11, decidedly lyrical, predominate. As it grew, "Song of Myself" attained more formal determinacy, be it through the 52 sections or the fleshing out of many individual lines and episodes.

In sum, "Song of Myself," particularly in its original 1855 version, may well benefit from being called an epic because, like Milton's Paradise Lost, it successfully performs something "unattempted yet in prose or rhyme." Completed in its original shape well before the Civil War, it breathes throughout that air of optimism and potential and limitless enthusiasm that a young man (Whitman was 36 when it was published in 1855) may possess. If we had no other texts by Whitman, the 1855 "Song" could stand as his poetic testimony. We would in that case likely call it an epic based on its ambition.

Then the Civil War intervened. America turned darker. In Whitman's subsequent editions of Leaves of Grass, exuberance is tempered by knowledge of suffering and tragedy. The author's health waned after 1873. While Leaves of Grass becomes more comprehensive with every subsequent edition, the lyric mode, instantiated in countless moments of celebration and meditation and momentary insights, becomes more and more dominant as the collection grows into its final shape. The textual agglomeration 
and thematic diversification make the post-Civil War editions of Leaves of Grass more comprehensive, but not more epic. To the contrary: the lyric mode takes precedence.

\section{Whitman as Lyricist}

17 Approaching Whitman again now through the lens of Jonathan Culler's recent insights about lyric theory, I find Whitman's voice and form responding well to Culler's criteria. For Culler, lyric is an expressive form that relies on "ritualistic dimensions" (Culler J., 2016: 350) is an event, "a statement about this world" (350)-neither primarily a narrative nor again the mimetic representation of an event. Since Culler further considers the lyric a transhistorical phenomenon, one whose forms can wax and wane, disappear and reappear, it is potentially more rewarding to examine Whitman's work for its lyrical features. Within that context, then one should attend both to the lyrical forms of Whitman's own time-the stanzaic ballads, the long-established forms of English-language poetry-and also to recognizable lyrical features of epics, such as the use of stress, mnemotechnic devices such as alliteration, or formulaic set-pieces of invocations, descriptions of heroes, or their accoutrements. It is tempting to think that Culler wrote this sentence, "Lyrics hyperbolically risk animating the world, investing mundane objects or occurrences with meaning" (38) with Whitman in mind.

Culler's criteria seem to me to articulate the experience of reading a section, or sections, of Whitman's Leaves of Grass, whether it's the more continuous flow of the 1855 edition without titles for individual poem or whether it's the titled poems of the later editions. Since so many of Whitman's poems are titled in synchronicity with their first lines, each text functions as an opportunity to enter the unfolding of an event at a specific, iterable moment in time. The ritual features of Whitman's poems-the long prophetic line, the catalogues, the anaphoras and epiphoras, the bardic exclamations signaled by exuberant punctuation!-make them unmistakably Whitmanesque and hence easy to parody. But the event-character of the poems, a conceptual setup that allows meditations to body forth from the contemplation of a scene unfolding each time at this very moment of reading or performance-whether this be the activities of lusty wagon-drivers, carefree swimmers, or frightened runaways-marks the texts as supremely lyrical. Our reading experience is always again immediate; we never feel that we are reading a narrative of an event. Instead, we are present witnesses to that event. We memorize lines, or sequences of lines, not the structure of a Whitman poem, while we relish the joy (occasionally unmotivated) of his linguistic exuberance. In the middle of a century that saw British epics continue to be produced in steady pace (see Tucker), Whitman appears to have used the history and conventions of epic mainly as an apparatus, while the expressive center of his poetry is definitively lyrical. Returning our attention to the lyrical features of his works-note the many poems that have the word "Song" in their title-we can freshly appreciate Whitman's haecceitas, his beingin-the-moment, present and future, and continuing right up to our day. 


\section{BIBLIOGRAPHY}

Baldwin, David B., "Epic Structure", The Walt Whitman Archive.https://whitmanarchive.org/ criticism/current/encyclopedia/entry_440.html

Blanton, C.D., The Dialectical Poetics of Late Modernism, Oxford University Press, 2015.

Culler, Jonathan, The Theory of the Lyric, Cornell University Press, 2016.

Donoghue, Denis, The American Classics. A Personal Essay, Yale University Press, 2005.

---, "'Leaves of Grass' and American Culture", The Sewanee Review, vol. 111, no. 3, 2003, p. 347-374.

Dubrow, Heather, Genre (Methuen and Co., 1982), New York, Routledge Revival, 2014.

Hardwig, Bill, "Walt Whitman and the Epic Tradition: Political and Poetical Voices in 'Song of Myself", Walt Whitman Quarterly Review, vol. 17, no. 4, 2000, p. 166-188.

Karbiener, Karen, "Afterword," in Live-Oak, with Moss, by Walt Whitman, illustrated by Brian Selznick, Abrams ComicArts, 2019.

Matthiessen, F.O., American Renaissance. Art and Expression in the Age of Emerson and Whitman, Oxford University Press, 1941.

Miller, James E., Jr., The American Quest for a Supreme Fiction. Whitman's Legacy in the Personal Epic, University of Chicago Press, 1979.

---, Leaves of Grass. America's Lyric-Epic of Self and Democracy, Twayne Publishers, 1992.

---, "Whitman's Leaves and the American 'Lyric-Epic'", in Poems in their Place. The Intertextuality and Order of Poetic Collections, Neil Fraistat (ed.), University of North Carolina Press, 1986, p. 289-307.

Milton, John, The Complete Poetical Works of John Milton, Douglas Bush (ed.), Houghton Mifflin, 1965.

Pierce, Roy Harvey, "Toward an American Epic", The Hudson Review, vol. 12, no. 3, 1959, p. 362-377.

Tucker, Herbert, Epic: Britain's Heroic Muse, 1790-1910, Oxford University Press, 2008.

Tuggle, Lindsay, The Afterlives of Specimens. Science, Mourning, and Whitman's Civil War, University of Iowa Press, 2017.

Turpin, Zachary (intro. and ed.), Life and adventures of Jack Engle, an auto-biography: a story of New York at the present time in which the reader will find some familiar characters, by Walt Whitman, University of Iowa Press, 2017.

Whitman, Walt, Leaves of Grass. The Complete 1855 and 1891-92 Editions, with an introduction by John Hollander, Library of America Classics, 2011.

\section{NOTES}

1. Hardwig's 2000 article offers the best historical-critical summary to date of the epic/lyric debate in Whitman studies. 


\section{AUTHOR}

\section{THOMAS C. AUSTENFELD}

Professeur de littérature américaine à l'Université de Fribourg. Thomas.austenfeld@unifr.ch 